\title{
Seasonal variations in the functional performance of industrial low-moisture part-skim mozzarella over a 1.5-year period
}

\author{
C. M. To, ${ }^{1,2,3 *} \odot$ L. Vermeir, ${ }^{2} \odot$ B. Kerkaert, ${ }^{1}$ D. Van Gaver, ${ }^{1}$ P. Van der Meeren, ${ }^{2} \odot$ and T. P. Guinee ${ }^{3} \odot$ \\ ${ }^{1}$ Milcobel CV, Dairy Products and Ingredients (DPI), Kallo 9120, Belgium \\ ${ }^{2}$ Particle and Interfacial Technology Group, Department of Green Chemistry and Technology, Faculty of Bioscience Engineering, Ghent University, \\ Ghent 9000 , Belgium \\ ${ }^{3}$ Department of Food Chemistry and Technology, Teagasc Food Research Centre Moorepark, Fermoy, Co. Cork, Ireland P61 C996
}

\begin{abstract}
Seventy-five blocks of low-moisture part-skim mozzarella cheese were procured from an industrial cheese plant, and the relationships between the physicochemical and functional properties were evaluated during refrigerated storage. In total, cheeses were obtained from 1 cheese vat on 7 different production dates, at 2 to 4 monthly intervals, over a 1.5 -yr period; all cheeses were made using a standard recipe. The cheeses were held at $4^{\circ} \mathrm{C}$ for $0,1,2,4,8,16$, or $32 \mathrm{~d}$ and assayed for composition, primary proteolysis, serum distribution, texture profile analysis, heat-induced changes in viscoelastic behavior, cheese extensibility, and melt characteristics. The results demonstrated a substantial increase in serum uptake by the calcium-phosphate para-casein matrix between 1 and $16 \mathrm{~d}$ of storage with a concomitant improvement in the functional performance of the cheese. Extending the storage time to 32 $\mathrm{d}$ resulted in further changes in the functional quality, concurrent with ongoing increases in protein hydration and primary proteolysis. Differences in the measured characteristics between the cheeses obtained on different sampling occasions were evident. Principal component analysis separated the cheeses based on their variance in functional performance, which was found to be correlated mainly with the calcium content of the cheese. The results indicate that the manufacturing process should be tightly controlled to minimize variation in calcium content and enhance the quality consistency of the cheese.
\end{abstract}

Key words: low-moisture part-skim mozzarella, cheese characteristics, principal component analysis, process variability

Received June 8, 2020.

Accepted August 8, 2020.

*Corresponding author: ChakMing.To@UGent.be

\section{INTRODUCTION}

Low-moisture part-skim mozzarella (LMPS) is a plasticized cheese with a structure typically described as a fibrous calcium-phosphate para-casein network with occluded pools of serum and fat (Oberg et al., 1993). Plasticization is typically achieved by displacing the contiguous planes of the fat-filled calcium-phosphate para-casein matrix of the fermented curd ( $\mathrm{pH} \sim 5.1$ to 5.3 ) by heating $\left(\sim 58\right.$ to $\left.62^{\circ} \mathrm{C}\right)$, kneading, and stretching the curd in hot water or dilute brine (Fox et al., 2017). The supplied thermomechanical energy alters the interactions between proteins and bestows the cheese with the ability to form extendable strands and undergo limited oiling-off when subsequently baked on a pizza (Sharma et al., 2016; McMahon and Oberg, 2017).

According to several researchers, understanding the development of the curd structure during manufacturing and the overall interactions between the para-casein fibers could help in optimizing the functional quality of the cheese (Oberg et al., 1993; Feeney et al., 2001; Lucey et al., 2003). These linkages between facing casein polymers include calcium-phosphate bridges between colloidal calcium phosphate (CCP) and phosphoserine residues, Ca bridges between $\mathrm{Ca}$ ions and dissociated AA residues, and hydrophobic attractions between hydrophobic protein domains (McMahon et al., 1999; Lucey et al., 2003; Fox et al., 2017). The overall balance of interactions is likely to be affected by many factors including cheese composition (e.g., pH, content of protein, moisture, fat, and calcium), degree of proteolysis, shear work input during curd stretching, curd temperature during manufacturing, storage, and cheese application. Smith et al. (2017) investigated the effects of refrigerated storage on the microstructure of a 10-kg industrial mozzarella cheese block and demonstrated how changes in hydrophobic interactions and proteolytic breakdown were significant drivers in the alteration of the calcium-phosphate para-casein matrix. In particular, free moisture, as measured by ${ }^{1} \mathrm{H}-\mathrm{NMR}$ relaxometry, was gradually taken up by the para-casein 
matrix within $20 \mathrm{~d}$ after manufacturing of the cheese, with a concomitant weakening of the hydrophobic interactions. These results were in agreement with those of Kuo and Gunasekaran (2009) and McMahon et al. (1999) who investigated the microstructure of LMPS mozzarella cheeses during 14 or $21 \mathrm{~d}$ of storage at $4^{\circ} \mathrm{C}$ using scanning electron microscopy, and described how the uptake of moisture resulted in swelling of the calcium-phosphate para-casein matrix, and the formation of a reticular network of distinctly defined fat globules occluded by the para-casein matrix. Similarly, Gianferri et al. (2007) reported substantial displacement of "serum water," described as the accumulated water in protein fiber channels, to "junction zone water," defined as the water that could be seen as an integral part of the protein structure, in retail mozzarella di Bufala Campana cheese (moisture content of 55 to $60 \%$, wt/wt) during storage at $8^{\circ} \mathrm{C}$ for $7 \mathrm{~d}$.

Other studies focused on the biochemical and thermophysical (functional, baking) properties of LMPS mozzarella during refrigerated storage. Increasing storage temperature of LMPS mozzarella from 0 to $15^{\circ} \mathrm{C}$ over a 70-d period resulted in more rapid depletion of expressible serum during the first $20 \mathrm{~d}$, higher primary proteolysis and flow over $70 \mathrm{~d}$, and higher extensibility after 5 to $20 \mathrm{~d}$ (Feeney et al., 2001; Guinee et al., 2001). Similar effects of storage time on the functional performance have been reported for LMPS mozzarella cheeses, manufactured on pilot-scale (Guinee et al., 2002; Dave et al., 2003; Imm et al., 2003; Banville et al., 2013).

Previous studies (Smith et al., 2017; Vermeir et al., 2019) evaluated storage-related changes in industrial LMPS mozzarella using ${ }^{1} \mathrm{H}$-nuclear magnetic resonance (NMR) relaxometry, but did not relate these changes to the concurrent changes in other physicochemical or functional characteristics. The objectives of the current study were first to establish the relationships between the biochemical, water distribution, and functional characteristics in industrial LMPS mozzarella cheeses during storage at $4^{\circ}$, and second to monitor inter-vat variability in these characteristics between the cheeses sampled on 7 different production dates over a 1.5-yr period. Identifying the source of this variability could afford manufacturers with a clearer view of the factors that affect quality, and thereby assist the production of cheese with a more consistent quality.

\section{MATERIALS AND METHODS}

\section{Manufacturing of LMPS Mozzarella}

The LMPS mozzarella was manufactured at Milcobel CV (Langemark, Belgium) following a standardized procedure. Milk was standardized to a fat content of $2.8 \%$ (wt/wt), pasteurized, cooled to $35^{\circ} \mathrm{C}$, pumped to the cheese vat, and inoculated with a freeze-dried culture (Streptococcus thermophilus). Then, $\mathrm{CaCl}_{2}$ $(33 \%$, wt/wt) was added to a final concentration of $0.42 \mathrm{mM}$ Ca. A commercial liquid microbial coagulant EC 3.4.23.23 (endopeptidase derived from Rhizumucor miehei) was dosed at a level of 23.83 international milk clotting units/L of milk. The milk was allowed to stand for approximately $30 \mathrm{~min}$ during which time it gelled. The gel was cut into curd grains, and the curd-whey mixture was stirred for $\sim 20 \mathrm{~min}$ and cooked at $39^{\circ} \mathrm{C}$ for $\sim 20 \mathrm{~min}$. After curd cooking, the whey was drained and the curd grains were collected on a transport belt and held at $35^{\circ} \mathrm{C}$ to promote curd dehydration and acidification, which resulted in fusing of the curd grains into a consolidated curd mass. When the curd attained a $\mathrm{pH}$ of 5.05 to 5.25 , it was milled, diced, heated to $62^{\circ} \mathrm{C}$ using a water-steam mixture, and kneaded and stretched mechanically into a hot uniform molten mass. The stretched curd was extruded into a mat, sprinkled with salt $(0.9 \%$, wt $/ \mathrm{wt})$, molded into blocks $(2.5 \mathrm{~kg}$; $28 \mathrm{~cm} \times 10 \mathrm{~cm} \times 8 \mathrm{~cm})$, and held in a brining bath at $4^{\circ} \mathrm{C}$ until the core of the cheeses was cooled down to $4^{\circ} \mathrm{C}$. After brining, the cheese blocks were drip-dried, packaged, and stored at $4^{\circ} \mathrm{C}$.

\section{Experimental Analysis}

Production. Every 2 to 4 mo over a period of 16 mo (November 2017-February 2019), a cheese vat (coded A, B, C, D, E, F, or G) was sampled to determine the effects of variability in milk composition, cheese $\mathrm{pH}$ at different stages of manufacture, and cheese composition on the functional characteristics of the cheese. Every production batch was performed with the same thermophilic starter culture and commercial rennet, and the process was operated under standardized conditions (time, temperature, and amount of water-steam mixture injected during curd plasticization).

Sampling. For each production date, the milk was stirred and sampled before rennet was added. A sample of the curd-whey mixture was collected during whey drainage, such that the sample corresponded to the middle of the cheese vat. A portion of the fermented curd was sampled from the transport belt before milling, such that the sample corresponded to the middle of the cheese vat. The milk, curd-whey, and curd samples were analyzed for $\mathrm{pH}$ (Knick, 765 Laboratory $\mathrm{pH}$ meter, SE 503 pH sensor, Berlin, Germany) directly after sampling; the results were denoted as $\mathrm{pH}_{\text {renneting, }}$ $\mathrm{pH}_{\text {drainage }}$, and $\mathrm{pH}_{\text {milling}}$, respectively. The milk samples were stored at $4^{\circ} \mathrm{C}$ for less than $8 \mathrm{~h}$ and analyzed for fat and protein (Milcoscan FT2, Foss, Hillerød, Denmark). 
Table 1. Sampling pattern of blocks per production date and per storage time at $4^{\circ} \mathrm{C}(\mathrm{d})^{1}$

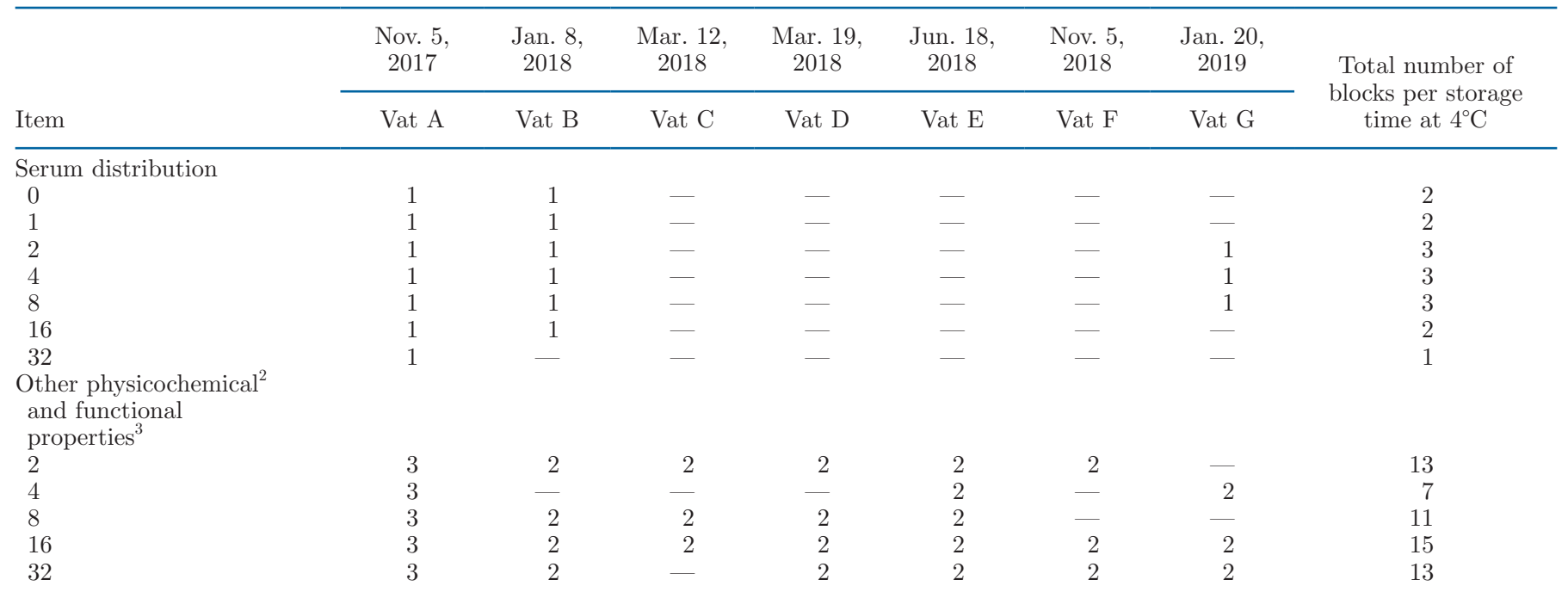

${ }^{1}$ The physicochemical and functional properties of industrial low-moisture part-skim mozzarella cheeses were evaluated during storage at $4{ }^{\circ} \mathrm{C}$. ${ }^{2}$ Other physicochemical properties: $\mathrm{pH}$, serum-soluble $\mathrm{Ca}$, and $\mathrm{pH} 4.6$ soluble $\mathrm{N}$.

${ }^{3}$ Functional properties: firmness, springiness, cohesiveness, and chewiness of the unheated cheese, and crossover temperature, maximum value of the loss tangent, extension work at 0 or 5 min after melting, and flow of the heated cheese.

Consecutive cheese blocks were removed at the end of the production line, such that the sampled blocks corresponded to the middle of the cheese vat. This was chosen to minimize the inter-block variability between cheeses taken from the same vat. After sampling, the cheeses were sealed in plastic vacuum bags and stored at $4^{\circ} \mathrm{C}$ for up to $32 \mathrm{~d}$. A total of 75 industrial cheese blocks were sampled. An overview of the sampling pattern of the blocks per production date and per storage time is given in Table 1. The serum distribution was evaluated in separate cheese blocks due to the difference in location between the analytical instruments.

Cheese Composition. Grated LMPS mozzarella was analyzed for moisture, fat, total N, salt, Ca, and $\mathrm{pH}$, as described previously (To et al., 2020). Moisture, fat, and $\mathrm{pH}$ were measured in duplicate on each cheese block. Total N, salt, and Ca were measured in duplicate on each cheese block from vat A during storage. For the subsequent cheese vats (vats B, C, D, E, F, and G), the contents of total $\mathrm{N}$, salt, and $\mathrm{Ca}$ were analyzed in duplicate on at least 4 cheese blocks after 2 or $4 \mathrm{~d}$ of storage.

Soluble $C a$ and $p H 4.6$ Soluble $N$. The levels of soluble $\mathrm{Ca}$ and $\mathrm{pH} 4.6$ soluble $\mathrm{N}(\mathbf{p H} 4.6 \mathrm{SN})$ were determined on a water-soluble extract of the cheese, as described previously by To et al. (2020). Serum-soluble Ca was expressed as a percentage of the total cheese Ca content and pH4.6SN was expressed as a percent- age of total cheese N. Measurements were performed in duplicate per cheese block.

Time-Domain ${ }^{1} \boldsymbol{H}$ NMR Relaxometry. The $\mathrm{T}_{2}$ relaxation time distribution of LMPS mozzarella was evaluated by low-field NMR on a benchtop Maran Ultra spectrometer (Oxford Instruments, Abingdon, UK), operating at $0.55 \mathrm{~T}\left(23.4 \mathrm{MHz}\right.$ for $\left.{ }^{1} \mathrm{H}\right)$. The method was described by Vermeir et al. (2019) who distinguished 3 serum fractions comprising liquid oil protons and water protons in LMPS mozzarella with different $T_{2}$ relaxation times. The serum fraction characterized by a $\mathrm{T}_{2}$ $>60 \mathrm{~ms}$ was ascribed to weakly interacting serum protons and could be interpreted as more-mobile-serum, whereas the other serum fractions, characterized by $\mathrm{T}_{2}$ $<3 \mathrm{~ms}$ or $\mathrm{T}_{2} \approx 10 \mathrm{~ms}$, were interpreted as less-mobileserum. In this study, the integrated signal intensity of the less-mobile-serum fractions, $\mathbf{A}_{3 \mathrm{~ms}}$ and $\mathbf{A}_{10 \mathrm{~ms}}$, and the more-mobile-serum fraction, $\mathbf{A}_{60 \mathrm{~ms}}$, were reported. The $A_{3 \mathrm{~ms}}$ and $\mathrm{A}_{10 \mathrm{~ms}}$ were indicative of serum that interacted with the calcium-phosphate para-casein network of the cheese, whereby shorter $\mathrm{T}_{2}$ times indicated stronger interactions. Triplicate measurements were performed at 2 separate locations in one mozzarella block after $0,1,2,4,8,16$ or $32 \mathrm{~d}$ storage at $4^{\circ} \mathrm{C}$, sampled from vats $\mathrm{A}, \mathrm{B}$, or $\mathrm{G}$ (Table 1 ). The data were used to monitor the behavior of cheese serum during refrigerated storage and its relation to the functional performance of the cheese. 
Functional Properties. The methods for assaying the functional performance of the cheese have been described previously in detail (To et al., 2020) and are summarized below.

Texture Profile Analysis. Cheese cubes $(25 \mathrm{~mm}$ $\times 25 \mathrm{~mm} \times 25 \mathrm{~mm}$ ) were loaded individually on a TAHDi texture analyzer fitted with a $100-\mathrm{kg}$ load cell (Stable Micro Systems, Goldalming, UK), and compressed in 2 consecutive bites at a speed of $1 \mathrm{~mm} / \mathrm{s}$ to $60 \%$ of its original height. The following characteristics were reported: maximum compression force recorded during bite 1 (firmness), the ratio of height to which the cube was compressed at the start of bite 2 relative to the sample's original height (springiness), the ratio of work required to compress the cube in bite 2 relative to that of bite 1 (cohesiveness), and the product of firmness $\times$ springiness $\times$ cohesiveness (chewiness). Measurements were performed in sextuplicate per cheese block.

Extensibility of the Heated Cheese. Shredded cheese was heated to $95^{\circ} \mathrm{C}$ and the molten curd $\left(85-95^{\circ} \mathrm{C}\right)$ was loaded on a TAHDi texture analyzer (Stable Micro Systems) and uniaxially extended at a rate of $10 \mathrm{~mm} / \mathrm{s}$ to a height of $380 \mathrm{~mm}$. Extension work was defined as the cumulative work required to extend the hot molten cheese, directly after heating $\left(\mathbf{E W}_{\mathbf{0}}\right)$, and after allowing the cheese to cool down for 5 min at room temperature $\left(\mathbf{E W}_{\mathbf{5}}\right)$. The $\mathrm{EW}_{0}$ and $\mathrm{EW}_{5}$ were measured in triplicate and in duplicate per cheese block, respectively. The $\mathrm{EW}_{5}$ was used to simulate the impact of cooling-induced stiffening of molten cheese on a pizza during consumption and was assessed for cheeses sampled from vats C, D, E, F, and G.

Heat-Induced Changes in Viscoelastic Behavior. Cheese discs (50 mm diameter; $2 \mathrm{~mm}$ thickness) were placed between parallel cross-hatched plates (PP50/P2-SN27902; INSET I-PP50/SS/P2) on a strain-controlled rheometer (MCR501, Anton Paar GmbH, Graz, Austria), subjected to a low amplitude shear strain $(\gamma=0.0063)$ at an angular frequency of $1 \mathrm{~Hz}$ and heated from $25^{\circ} \mathrm{C}$ to $90^{\circ} \mathrm{C}$. The crossover temperature (COT), corresponding to the point at which the cheese transitioned from the solid phase into the liquid phase, and the maximum value of the loss tangent $\left(\mathbf{L} \mathbf{T}_{\max }\right)$, an index for the fluidity of the cheese during heating, were reported. Measurements were performed in duplicate per cheese block.

Flow. Cheese discs (45 mm diameter; $4 \mathrm{~mm}$ thickness) were heated at $280^{\circ} \mathrm{C}$ for $4 \mathrm{~min}$ in a convection oven (Binder FD 35, Binder GmbH, Tuttlingen, Germany). Flow was defined as the percentage increase in mean diameter during heating. Measurements were performed in quadruplicate per cheese block.

\section{Statistical Analysis}

The LMPS mozzarella was manufactured on 7 different production dates according to a standardized procedure. The cheeses from the different production dates were analyzed for changes in physicochemical and functional characteristics during storage, and the data were analyzed using a randomized incomplete block design incorporating storage time as the treatment and 7 blocks (replicate trials). The JMP 14 statistical software package (SAS Institute Inc., Cary, NC) was used to determine significant differences between mean compositional values of cheeses obtained from different vats by 1-way ANOVA and Tukey's honestly significant difference post-hoc test.

The relationships between the physicochemical $\left(\mathrm{A}_{3 \mathrm{~ms}}\right.$, $\mathrm{pH}$, serum-soluble $\mathrm{Ca}$, and $\mathrm{pH} 4.6 \mathrm{SN}$ ) and functional (firmness, $\mathrm{COT}, \mathrm{LT}_{\max }, \mathrm{EW}_{0}$, and flow) characteristics of the cheeses during storage at $4^{\circ} \mathrm{C}$ were evaluated using simple linear regression analysis, and the significance was determined by application of an $F$-test with $\mathrm{n}-2$ df.

The variability in the characteristics of the cheeses during storage at $4^{\circ} \mathrm{C}$ was evaluated using principal component analysis (PCA), which identifies linear combinations of correlated variables (i.e., principal components), while retaining the highest amount of variability among the studied variables. First, the Kaiser-Meyer-Olkin (KMO) test and Bartlett's test of sphericity were used to test the sampling adequacy and the degree of correlation between variables, respectively. The KMO test measures the proportion of variance that could be attributed to underlying principal components, whereas the Bartlett's test of sphericity tests the correlation matrix against the identity matrix. Principal component analysis was performed when the KMO value was larger than 0.6 and when the Bartlett's test of sphericity returned significant at $P<0.05$, and the minimal number of principal components was derived based on eigenvalues larger than 1, Skree plot analysis, and the cumulative percentage of variance explained. Varimax rotation was used to obtain principal components that were not correlated and to reduce the number of variables.

Two-way ANOVA was then used to determine the effects of variations in the composition, storage time at $4^{\circ} \mathrm{C}$, and their interactions on the functional performance-related components, separately. The level of significance was determined at $\alpha=0.05$ throughout. For each functional performance-related component, the "fit model" function of JMP 14 was used to fit a linear model to the variables that were found to have a significant effect. 


\section{RESULTS AND DISCUSSION}

\section{In-Line Process Analysis}

The mean fat and protein content of the milk used for cheesemaking was $2.83 \%$ and $3.67 \%$, respectively. The variability in the contents of fat and protein at the 7 different production dates over the 1.5 -yr period is indicated by the difference between the maximum and minimum value of the measured data, divided by the average (Table 2), and reflects the width of the distribution for a given average on the condition that the data are normally distributed and no significant outliers are present. The milk protein content showed a variability of $8.4 \%$ in the current study, which was consistent with the data reported by Eurostat (2020), which reported a variability of $7.6 \%$ in the protein content (in nonfat DM) of Belgian raw milk for the year 2019, and reflects the natural variation associated with differences in breed, feed type, season, or stage of lactation. Walstra et al. (2006) reported that the fat content in raw milk showed the highest variability among all milk constituents. As legal "Standards of Identity" impose fat-in-dry matter (FDM) specifications on many cheese varieties, this highlights the importance of fat standardization for cheesemaking (Fox et al., 2017).

The curd becomes suitable for plasticization when sufficient $\mathrm{Ca}$ is released from the calcium-phosphate para-casein network, and is governed by the values for $\mathrm{pH}_{\text {renneting, }}, \mathrm{pH}_{\text {drainage }}$, and $\mathrm{pH}_{\text {milling }}$, which upon decrease promote solubilization of colloidal Ca by displacement with acidic protons (Fox et al., 2017; McMahon and
Oberg, 2017). The former 2 values are critical for mediating the total Ca content of the curd, and hence the $\mathrm{pH}$ of the curd at which sufficient $\mathrm{Ca}$ is released (Kindstedt et al., 2004; McMahon and Oberg, 2017). Typical $\mathrm{pH}_{\text {drainage }}$ and $\mathrm{pH}_{\text {milling }}$ values of 6.20 to 6.00 and 5.15 to 5.30 are reported, in respective order, for the production of LMPS mozzarella (Fox et al., 2017; McMahon and Oberg, 2017). The mean values for $\mathrm{pH}_{\text {renneting, }} \mathrm{pH}_{\text {drainage, }}$ and $\mathrm{pH}_{\text {milling }}$ over the 7 cheesemaking days in the present study were $6.54,6.37$, and 5.15 for this particular long shelf life recipe, respectively. The average $\mathrm{pH}_{\text {drainage }}$ applied by the plant in this study was relatively high, and a $\mathrm{pH}_{\text {milling }}$ near the lower limit was required to plasticize the curd. The mean Ca content of the resulting cheeses in this study (29.9 $\mathrm{mg}$ of $\mathrm{Ca} / \mathrm{g}$ of protein) was relatively high when compared with those reported by Guinee et al. (2000), who evaluated the composition of 8 commercial low-moisture mozzarella cheeses $(22.6$ to $31.1 \mathrm{mg}$ of $\mathrm{Ca} / \mathrm{g}$ of protein), and thus reflects the wide range of $\mathrm{pH}_{\text {renneting, }} \mathrm{pH}_{\text {drainage }}$, and $\mathrm{pH}_{\text {milling }}$ applied in commercial practices.

All cheeses conformed to the specifications of DM and FDM for low-moisture part-skim mozzarella, as defined by the Code of Federal Regulation (48\%, wt/wt $<\mathrm{DM}<55 \%$, wt $/$ wt; $30 \%$, wt $/$ wt $<\mathrm{FDM}<45 \%$, wt $/$ wt) (FDA, 2020). The mean values for the contents of DM, FDM, moisture-nonfat-substances (MNFS), saltin-moisture $(\mathbf{S} / \mathbf{M})$, and Ca differed between production dates at $P<0.05$, with $\mathrm{S} / \mathrm{M}$ and Ca showing the highest variability. Variability likely reflects differences in milk composition (levels of protein, fat, lactose, and $\mathrm{Ca} ; \mathrm{pH}$ ) and manufacturing process (ratio of added ren-

Table 2. Details of the cheesemaking process and the composition of the resultant cheeses obtained at different production dates ${ }^{1}$

\begin{tabular}{|c|c|c|c|c|c|c|c|c|}
\hline \multirow[b]{2}{*}{ Item } & $\begin{array}{c}\text { Nov. 5, } \\
2017\end{array}$ & $\begin{array}{c}\text { Jan. 8, } \\
2018\end{array}$ & $\begin{array}{c}\text { Mar. 12, } \\
2018\end{array}$ & $\begin{array}{c}\text { Mar. 19, } \\
2018\end{array}$ & $\begin{array}{c}\text { Jun. 18, } \\
2018\end{array}$ & $\begin{array}{c}\text { Nov. } 5 \text {, } \\
2018\end{array}$ & $\begin{array}{c}\text { Jan. 20, } \\
2019\end{array}$ & \multirow{2}{*}{$\begin{array}{c}\text { Variability } \\
(\%)\end{array}$} \\
\hline & Vat A & Vat B & Vat $\mathrm{C}$ & Vat D & Vat E & Vat $\mathrm{F}$ & Vat $\mathrm{G}$ & \\
\hline \multicolumn{9}{|l|}{ Milk composition } \\
\hline Fat $(\%, w t / w t)$ & 2.84 & 2.87 & 2.86 & 2.86 & 2.82 & 2.77 & 2.76 & 3.9 \\
\hline Protein $(\%, w t / w t)$ & 3.73 & 3.68 & 3.66 & 3.64 & 3.47 & 3.75 & 3.78 & 8.4 \\
\hline \multicolumn{9}{|l|}{ Cheese manufacture $^{2}$} \\
\hline $\mathrm{pH}_{\text {milling }}$ & 5.19 & 5.15 & 5.15 & 5.11 & 5.06 & 5.16 & 5.17 & 2.5 \\
\hline \multicolumn{9}{|l|}{ Cheese composition ${ }^{2}$} \\
\hline $\mathrm{DM}(\%, \mathrm{wt} / \mathrm{wt})$ & $51.6 \pm 0.5^{\mathrm{c}}$ & $52.1 \pm 0.4^{\mathrm{bc}}$ & $52.0 \pm 0.3^{\mathrm{bc}}$ & $52.1 \pm 0.4^{\mathrm{b}}$ & $52.1 \pm 0.2^{\mathrm{b}}$ & $52.9 \pm 0.3^{\mathrm{a}}$ & $52.0 \pm 0.2^{\mathrm{bc}}$ & 2.5 \\
\hline FDM $(\%)$ & $41.8 \pm 0.5^{\mathrm{bc}}$ & $42.3 \pm 0.5^{\mathrm{ab}}$ & $41.8 \pm 0.5^{\mathrm{bc}}$ & $42.7 \pm 0.5^{\mathrm{a}}$ & $41.4 \pm 0.4^{\mathrm{c}}$ & $41.4 \pm 0.6^{\mathrm{bc}}$ & $41.9 \pm 0.4^{\mathrm{bc}}$ & 3.1 \\
\hline MNFS (\%) & $61.7 \pm 0.6^{\mathrm{a}}$ & $610.5 \pm 0.3^{\mathrm{abc}}$ & $61.3 \pm 0.5^{\mathrm{ab}}$ & $61.6 \pm 0.6^{\mathrm{ab}}$ & $61.1 \pm 0.3^{\mathrm{bc}}$ & $60.3 \pm 0.5^{\mathrm{c}}$ & $61.4 \pm 0.4^{\mathrm{ab}}$ & 2.3 \\
\hline $\mathrm{S} / \mathrm{M}(\%)$ & $2.7 \pm 0.1^{\mathrm{a}}$ & $2.7 \pm 0.1^{\mathrm{a}}$ & $2.5 \pm 0.1^{\mathrm{b}}$ & $2.3 \pm 0.1^{\mathrm{b}}$ & $2.4 \pm 0.0^{\mathrm{b}}$ & $2.4 \pm 0.1^{\mathrm{ab}}$ & $2.0 \pm 0.3^{\mathrm{c}}$ & 28.8 \\
\hline $\mathrm{Ca}(\mathrm{mg} / \mathrm{g}$ of protein) & $32.6 \pm 1.4^{\mathrm{a}}$ & $31.1 \pm 0.6^{\mathrm{ab}}$ & $27.3 \pm 0.7^{\mathrm{c}}$ & $28.5 \pm 0.7^{\mathrm{bc}}$ & $28.2 \pm 1.0^{\mathrm{bc}}$ & $30.9 \pm 2.9^{\mathrm{ab}}$ & $30.4 \pm 1.0^{\mathrm{ab}}$ & 17.6 \\
\hline
\end{tabular}

\footnotetext{
${ }^{\mathrm{a}-\mathrm{c}}$ Values in rows with different superscript letters denote a difference at $P<0.05$.

${ }^{1}$ Presented data for milk composition or cheese manufacture represent one measured value per vat, whereas data for cheese composition represent mean values with SD measured on at least 4 different cheeses per vat.

${ }^{2} \mathrm{pH}_{\text {renneting }}=\mathrm{pH}$ at rennet addition; $\mathrm{pH}_{\text {drainage }}=\mathrm{pH}$ at vat drainage; $\mathrm{pH}_{\text {milling }}=\mathrm{pH}$ at curd milling; $\mathrm{FDM}=$ fat-in-dry matter; $\mathrm{MNFS}=$ moisturenonfat-substances; $\mathrm{S} / \mathrm{M}=$ salt-in-moisture.
} 

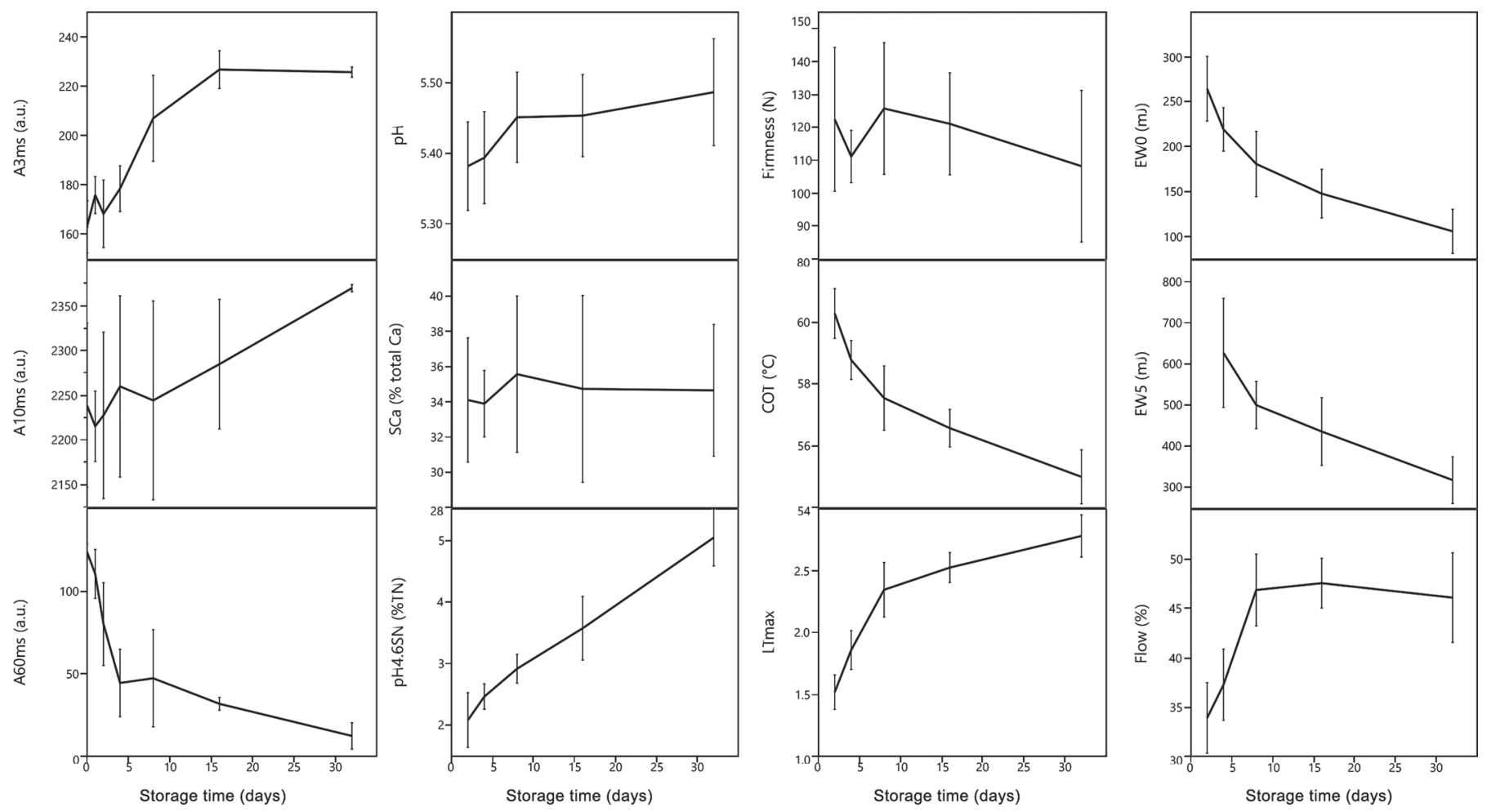

Figure 1. Overall changes during storage at $4^{\circ} \mathrm{C}$ in serum distribution [less-mobile-serum fractions $\left(\mathrm{A}_{3 \mathrm{~ms}}\right.$ and $\left.\mathrm{A}_{10 \mathrm{~ms}}\right)$, and more-mobile-serum fraction $\left(\mathrm{A}_{60 \mathrm{~ms}}\right)$ ], cheese $\mathrm{pH}$, serum-soluble $\mathrm{Ca}(\mathrm{SCa})$, primary proteolysis [as measured by the level of $\mathrm{pH} 4.6 \mathrm{soluble} \mathrm{N}(\mathrm{pH} 4.6 \mathrm{SN})$ ], firmness, crossover temperature $(\mathrm{COT})$, maximum value of the loss tangent $\left(\mathrm{LT}_{\max }\right)$, extension work at 0 or 5 min after melting $\left(\mathrm{EW}_{0}\right.$ or $\mathrm{EW}_{5}$, respectively), and flow of commercial low-moisture part-skim mozzarella cheeses. The data presented are mean values of 7 different production dates, except for those for serum distribution properties, which were measured for 3 different production dates only (Table 1). Error bars represent the $\mathrm{SD} . \mathrm{TN}=$ total $\mathrm{N}$; a.u. $=$ arbitrary units.

net and starter culture to milk casein content, starter culture activity, $\mathrm{pH}$ at different stages of manufacture) across the cheesemaking season (Chen et al., 2014; Lin et al., 2017; Gulati et al., 2018, 2019). Such factors predetermine the composition and, ultimately, the biochemical and functional properties of the cheese (Fox et al., 2017). The relatively high variability between different production dates for $\mathrm{Ca}$ and $\mathrm{S} / \mathrm{M}$ is consistent with that previously reported for industrial mozzarella and Cheddar cheeses (Guinee et al., 2000), which may be associated with differences in rate of acid development and curd $\mathrm{pH}$ profile at different stages of manufacture. Acid development, which is influenced by the interactive effects of many compositional and cheesemaking variables, is a key determinant for Ca release from, and salt uptake by, curd on transit through the manufacturing process (Fox et al., 2017).

\section{Overall Changes During Storage at $4^{\circ} \mathrm{C}$}

The storage-related changes in physicochemical and functional characteristics of cheese across the 7 different production dates are shown in Figure 1. The data for the individual vats at different storage times are available in Supplemental Table S1 (https://doi.org/10 .3168/jds.2020-19047).

Physicochemical Changes. Increasing storage time resulted in a reduction in more-mobile-serum $\left(\mathrm{A}_{60 \mathrm{~ms}} ; P\right.$ $<0.001)$ and increases in less-mobile-serum $\left(\mathrm{A}_{3 \mathrm{~ms}}\right.$ and $\left.\mathrm{A}_{10 \mathrm{~ms}} ; P<0.001\right)$, pH4.6SN $(P<0.001)$, and $\mathrm{pH}(P<$ $0.05)$. The trends concur with those of previous studies (Guo and Kindstedt, 1995; Guinee et al., 2002; Smith et al., 2017). Smith et al. (2017) suggested that the reduction in $\mathrm{A}_{60 \mathrm{~ms}}$ was related to the increase in soluble Ca content during early storage (e.g., 20 d; Guo and Kindstedt, 1995; O'Mahony et al., 2006), concomitant with the solubilization of $\mathrm{CCP}$, and hypothesized that the CCP solubilization would expose the highly polar phosphoserine groups of the casein and thereby promote water immobilization through hydrogen bonding. Additionally, salt in the cheese contributes to salting-in and hydration of the casein during early storage (Guo et al.,1997) due to exchange of casein-bound Ca with Na. The increase in $\mathrm{pH}$ is of comparable magnitude to that reported previously for LMPS mozzarella (Guo et al., 1997; Guinee et al., 1998) and has been attributed to 
a storage-related increase in the solubilization of CCP and the $\mathrm{pH}$-upward buffering effect associated with the protonation of the released phosphate groups $\left(\mathrm{HPO}_{4}{ }^{2-}\right)$ in the serum phase (Upreti et al., 2006; Smith et al., 2017).

Storage time did not affect the proportion of serumsoluble Ca at $P>0.05$, which varied from $28 \%$ to $43 \%$ of total Ca (Figure 1). This trend contrasts with that of Guo and coworkers (Guo and Kindstedt, 1995; Guo et al., 1997) who found a significant increase in the concentration of $\mathrm{Ca}$ in serum expressed from LMPS mozzarella cheese on centrifugation at $12,500 \times g$ over the first $8 \mathrm{~d}$ of storage; simultaneously, the volume of expressible serum decreased. However, the current results agree with those of Metzger et al. (2001) who showed that the soluble Ca content (as \% of total Ca in cheese) of a water-soluble extract of LMPS mozzarella, prepared by filtration of a cheese-water homogenate, changed little from 40 to $45 \%$ over the course of a $90-d$ storage period at $4^{\circ} \mathrm{C}$. The discrepancy between these findings may be attributed to variations in curd temperature at stretching. Metzger et al. (2001) applied a similar temperature at curd stretching $\left(62.3^{\circ} \mathrm{C}\right)$ to that in the current study $\left(\sim 62^{\circ} \mathrm{C}\right)$, whereas Guo and Kindstedt (1995) and Guo et al. (1997) stretched the curd at a lower temperature $\left(54^{\circ} \mathrm{C}\right)$. These stretching temperatures were in accordance with the values reported for commercial practices $\left(50\right.$ to $65^{\circ} \mathrm{C}$; Renda et al., 1997) and may differ depending on the intended markets. For example, higher stretch temperatures may be applied to render the cheese more firm during storage through greater inactivation of the starter culture and residual coagulant activity (Feeney et al., 2001). Kindstedt et al. (1995) increased the plasticization temperature from 62 to $66^{\circ} \mathrm{C}$ by varying the screw speed and found that higher plasticization temperatures resulted in cheeses with lower amounts of serum-soluble $\mathrm{Ca}$ and increased firmness during storage at $4^{\circ} \mathrm{C}$, thereby indicating that a slight increase in curd temperature during stretching may already induce a shift in Ca distribution to the casein-bound state, and thus promote the aggregation of the calcium-phosphate para-casein network (Kindstedt et al., 2004). The discrepancy between results may also be attributed to differences in curd stretching time. Sharma et al. (2016) investigated the effects of shear work input during curd stretching on the viscoelastic properties of 3 model mozzarella cheeses at fixed screw speeds. Longer stretching times at fixed screws speed resulted in cheeses with increased stiffness and reduced flow upon heating. The authors proposed that the cheese structure transitioned from an entangled polymer network to a highly aggregated network of casein particles with enhanced Ca bridging. It is likely that the extraction method, conditions of extraction, and in particular $\mathrm{pH}$ of the cheese after manufacture and changes in $\mathrm{pH}$ during storage further affected the proportion of serum-soluble Ca in LMPS mozzarella (Guinee et al., 2000; Metzger et al., 2001; Hassan et al., 2004).

Functional Properties. The springiness or cohesiveness of the unheated cheese decreased $(P<0.001)$ during storage at $4^{\circ} \mathrm{C}$ (graphs not shown), whereas firmness remained unchanged at $P>0.05$ (Figure 1). These results were in contrast with those of Yun et al. (1993a), who found no effects of storage for up to $50 \mathrm{~d}$ at $4^{\circ} \mathrm{C}$ on the cohesiveness of unheated LMPS mozzarella, whereas hardness and springiness decreased significantly. The lack of storage-related effects on hardness may reflect the inter-vat variation in composition or the relatively low levels of pH4.6SN (Yun et al., 1993b).

The mean values for $\mathrm{COT}, \mathrm{EW}_{0}$ and $\mathrm{EW}_{5}$ decreased during storage at $4^{\circ} \mathrm{C}(P<0.001)$, whereas those for $\mathrm{LT}_{\max }$ and flow increased $(P<0.001)$. These trends were consistent with the increases in $\mathrm{A}_{3 \mathrm{~ms}}$ and $\mathrm{pH} 4.6 \mathrm{SN}$. We found the largest changes in serum distribution $\left(\mathrm{A}_{3 \mathrm{~ms}}\right.$ and $\left.\mathrm{A}_{60 \mathrm{~ms}}\right)$ and functional performance (COT, $\mathrm{LT}_{\max }, \mathrm{EW}_{0}$, and flow) during the first $16 \mathrm{~d}$ of storage after which the rate of change decreased markedly. In contrast, the pH4.6SN increased linearly over the 32 d of storage. Similar trends were reported by Guinee et al. (2001) and Imm et al. (2003). Increases in protein hydration and proteolysis have been considered as factors that facilitate the displacement of the calciumphosphate para-casein network when the cheese is subjected to heating, extension, and shear stresses during baking and consumption, with consequent increases in $\mathrm{LT}_{\max }$ and flow, and decreases in COT, $\mathrm{EW}_{0}$, and $\mathrm{EW}_{5}$ during storage at $4^{\circ} \mathrm{C}$ (McMahon et al., 1999; Guinee et al., 2001; McMahon and Oberg, 2017).

\section{Relationships Between Physicochemical and Functional Properties}

The relationships between physicochemical and functional characteristics of the cheeses are illustrated in Figure 2. Despite the scatter associated with the different production dates and storage time, linear regression analysis indicated significant relationships between characteristics of the heated cheese (COT, $\mathrm{LT}_{\max }, \mathrm{EW}_{0}$, and flow) and protein hydration $\left(\mathrm{A}_{3 \mathrm{~ms}}\right)$, or pH4.6SN (Table 3). Additionally, protein hydration and $\mathrm{pH} 4.6 \mathrm{SN}$ affected the springiness and cohesiveness of the unheated cheese but did not affect the firmness at $P<0.05$. Cheese $\mathrm{pH}$ varied from 5.3 to 5.6 and affected COT and $\mathrm{LT}_{\max }$, whereas the proportion of soluble $\mathrm{Ca}$ (28 to $42 \%$ ) affected cheese firmness only. The analysis confirms the importance of para-casein 


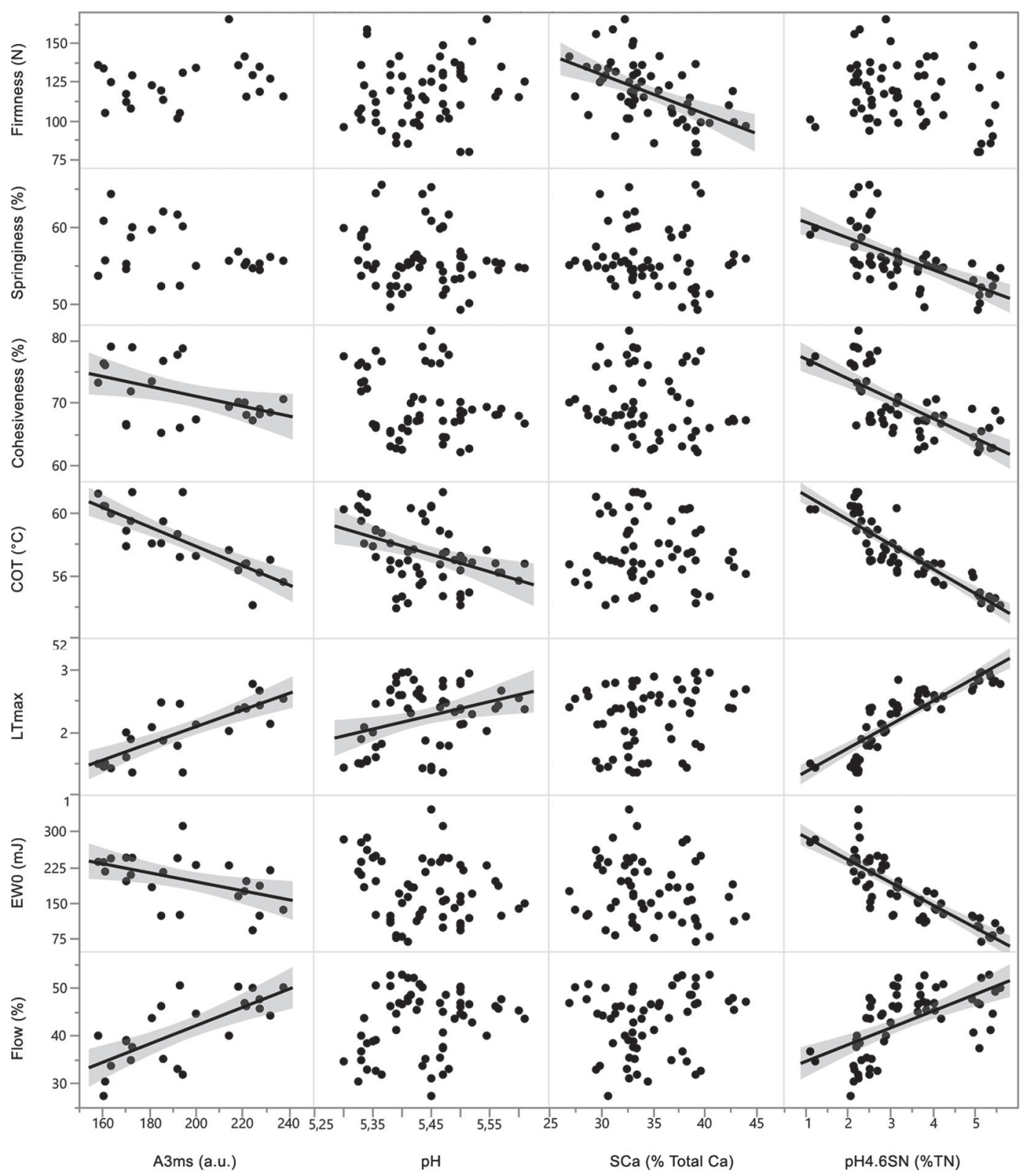

Figure 2. Relationships between physicochemical characteristics [less-mobile-serum fraction $\left(\mathrm{A}_{3 \mathrm{~ms}}\right)$; pH; serum-soluble calcium content (SCa); primary proteolysis, pH 4.6 soluble $\mathrm{N}$ (pH4.6SN)] and functional characteristics of the unheated (firmness, springiness, cohesiveness) and heated [crossover temperature $(\mathrm{COT})$, maximum value of the loss tangent $\left(\mathrm{LT}_{\max }\right)$, extension work at 0 min after melting $(\mathrm{EW})$, flow] cheeses. The data were obtained from 75 industrial low-moisture part-skim mozzarella cheese blocks sampled on 7 different production dates, and measured after $0,1,2,4,8,16$, or $32 \mathrm{~d}$ storage at $4^{\circ} \mathrm{C}$. Regression lines with $95 \%$ confidence limits are shown for significant relationships $(P<0.05) . \mathrm{TN}=$ total $\mathrm{N} ;$ a.u. $=$ arbitrary units.

hydration $\left(\mathrm{A}_{3 \mathrm{~ms}}\right)$ and hydrolysis $(\mathrm{pH} 4.6 \mathrm{SN})$ as modulating factors on the functionality of heated LMPS mozzarella. Typically, the increases in $\mathrm{A}_{3 \mathrm{~ms}}$ and $\mathrm{pH} 4.6 \mathrm{SN}$ in LPMS mozzarella during the first $16 \mathrm{~d}$ of refrigerated storage are critical in transforming its melting behavior and bestowing it with acceptable functionality when baked (e.g., smooth, fluid, extensible, and flowable cheese). The continued storage to $32 \mathrm{~d}$ promotes further changes in these factors, especially protein hydrolysis, and thereby further alters the functionality.

\section{Overall Variability in Industrial LMPS Mozzarella}

The mean values and standard deviation for the different compositional constituents are shown in Table 2 , and those of the physicochemical and functional 
Table 3. Relationships between physicochemical and functional characteristics of the unheated or heated cheese ${ }^{1}$

\begin{tabular}{|c|c|c|c|c|}
\hline Item & $\mathrm{df}_{\text {model }}$ & $\mathrm{df}_{\text {error }}$ & $F_{\text {ratio }}$ & $P$ \\
\hline \multicolumn{5}{|l|}{$\overline{\mathrm{A}_{3 \mathrm{~ms}}}$} \\
\hline Firmness & 1 & 22 & 1.61 & - \\
\hline Springiness & 1 & 22 & 2.95 & - \\
\hline Cohesiveness & 1 & 22 & 5.72 & $*$ \\
\hline Chewiness & 1 & 22 & 0.27 & - \\
\hline COT & 1 & 22 & 47.12 & $* * *$ \\
\hline $\mathrm{LT}_{\max }$ & 1 & 22 & 34.44 & $* * *$ \\
\hline $\mathrm{EW}_{0}$ & 1 & 22 & 6.61 & $* *$ \\
\hline Flow & 1 & 22 & 23.89 & $* * *$ \\
\hline \multicolumn{5}{|l|}{$\mathrm{SCa}$} \\
\hline Firmness & 1 & 57 & 9.34 & ** \\
\hline Springiness & 1 & 57 & 0.03 & - \\
\hline Cohesiveness & 1 & 57 & 1.39 & - \\
\hline Chewiness & 1 & 57 & 7.79 & $* *$ \\
\hline COT & 1 & 57 & 1.19 & - \\
\hline $\mathrm{LT}_{\max }$ & 1 & 57 & 3.28 & - \\
\hline $\mathrm{EW}_{0}$ & 1 & 57 & 1.43 & - \\
\hline Flow & 1 & 57 & 0.91 & - \\
\hline \multicolumn{5}{|l|}{$\mathrm{pH}$} \\
\hline Firmness & 1 & 57 & 2.03 & - \\
\hline Springiness & 1 & 57 & 1.49 & - \\
\hline Cohesiveness & 1 & 57 & 2.54 & - \\
\hline Chewiness & 1 & 57 & 0.15 & - \\
\hline $\mathrm{COT}$ & 1 & 57 & 10.79 & ** \\
\hline $\mathrm{LT}_{\max }$ & 1 & 57 & 6.83 & $*$ \\
\hline $\mathrm{EW}_{0}$ & 1 & 57 & 2.98 & - \\
\hline Flow & 1 & 57 & 3.60 & - \\
\hline \multicolumn{5}{|l|}{ pH4.6SN } \\
\hline Firmness & 1 & 57 & 3.48 & - \\
\hline Springiness & 1 & 57 & 36.90 & $* * *$ \\
\hline Cohesiveness & 1 & 57 & 55.62 & $* * *$ \\
\hline Chewiness & 1 & 57 & 28.66 & $* * *$ \\
\hline $\mathrm{COT}$ & 1 & 57 & 184.22 & $* * *$ \\
\hline $\mathrm{LT}_{\max }$ & 1 & 57 & 168.34 & $* * *$ \\
\hline $\mathrm{EW}_{0}$ & 1 & 57 & 137.22 & $* * *$ \\
\hline Flow & 1 & 57 & 31.97 & $* * *$ \\
\hline
\end{tabular}

${ }^{1} \mathrm{~A}_{3 \mathrm{~ms}}=$ less-mobile-serum; $\mathrm{SCa}=$ serum-soluble calcium content; $\mathrm{pH} 4.6 \mathrm{SN}=\mathrm{pH} 4.6$ soluble $\mathrm{N}$, primary proteolysis; $\mathrm{COT}=$ crossover temperature; $\mathrm{LT}_{\max }=$ maximum value of the loss tangent; $\mathrm{EW}_{0}=$ extension work at 0 min after melting.

Simple regression analysis between physicochemical $\left(\mathrm{A}_{3 \mathrm{~ms}}, \mathrm{pH}, \mathrm{SCa}\right.$, or pH4.6SN) and functional characteristics of the unheated (firmness, springiness, cohesiveness, or chewiness) or the heated cheese (COT, $\mathrm{LT}_{\max }, \mathrm{EW}_{0}$, or flow) was performed using data obtained on 75 industrial low-moisture part-skim mozzarella cheeses. The cheeses were sampled at 7 different production dates, and measured after $0,1,2,4$, 8,16 , or $32 \mathrm{~d}$ storage at $4^{\circ} \mathrm{C}$. The statistical significance $(P)$ is given where $P>0.05, P<0.05, P<0.01$, and $P<0.001$ are denoted by $*, * *$, and $* * *$, respectively.

characteristics after different storage times in Figure 1. Evaluation of this variability and identifying the causative factors potentially provide cheesemakers with clearer insight into the production of cheese of more consistent functional quality.

Principal Component Analysis. Principal component analysis was used to resolve relationships between physicochemical and functional characteristics of the cheeses, and to establish a quantifiable factor to describe the overall functional performance of the cheese, which was then used to separate the cheeses on the basis of storage time and production date. First, we simplified the current multivariable study by reducing the number of functional-performance-related and cheesemaking-related variables, separately (Supplemental Table S2; https://doi.org/10.3168/jds.2020-19047). Cheese-serum-related variables were not included in the PCA, as these were measured for 3 different production dates only (Supplemental Table S1; https://doi.org/10 .3168/jds.2020-19047) and sampling times did not correspond to those at which the remaining physicochemical and functional properties were evaluated.

Variation in Physicochemical and Functional Characteristics. Principal component analysis combined 3 physicochemical ( $\mathrm{pH}$, serum-soluble $\mathrm{Ca}$, and $\mathrm{pH} 4.6 \mathrm{SN}$ ) and 8 functional (firmness, springiness, cohesiveness, chewiness, COT, $\mathrm{LT}_{\max }, \mathrm{EW}_{0}$, and flow) variables into 2 principal components, PC1 and PC2, which accounted for $58.7 \%$ and $15.8 \%$ of the total variance in the measured data, respectively. The loadings plot (Figure 3A) illustrates how the variance in the original 11 response variables is explained by $\mathrm{PC} 1$ (x-axis) and $\mathrm{PC} 2$ (y-axis). The main variables contributing to a positive scoring on $\mathrm{PC} 1$ are cohesiveness, springiness, $\mathrm{EW}_{0}$, and COT, whereas those contributing to a negative scoring are $\mathrm{pH} 4.6 \mathrm{SN}, \mathrm{LT}_{\max }$, and flow. This indicated that $\mathrm{pH} 4.6 \mathrm{SN}$ correlated positively with flow and $\mathrm{LT}_{\max }$, but negatively with $\mathrm{EW}_{0}, \mathrm{COT}$, cohesiveness, and springiness. The relation between these variables was also evident from Figure 2 and is in agreement with other authors (Guinee et al., 2001, 2002; Sharma et al., 2016). The main variables contributing to a positive scoring on $\mathrm{PC} 2$ were $\mathrm{pH}$, firmness, and chewiness, whereas soluble $\mathrm{Ca}$ content contributed to a negative scoring. The PC1 and PC2 thus explain the variance in the physicochemical and functional properties of the cheese and could be used to separate the cheeses on the basis of storage time and production date. We illustrate this in the score plot (Figure 3B), where we group the mozzarella blocks assayed in this study according to their scorings on $\mathrm{PC} 1$ and $\mathrm{PC} 2$, such that the plot was divided into 4 quadrants: I, II, III, and IV. Cheeses in quadrant I scored positively for both $\mathrm{PC} 1$ and $\mathrm{PC} 2$, and thus had the highest values for $\mathrm{pH}$, firmness, springiness, cohesiveness, chewiness, $\mathrm{EW}_{0}$, and COT; such conditions would contribute to poor cheese functionality. In contrast, cheeses in quadrant III scored negatively on PC1 and PC2, and had the highest values for soluble $\mathrm{Ca}, \mathrm{pH} 4.6 \mathrm{SN}$, flow, and $\mathrm{LT}_{\max }$, which would favor an overall more desirable functionality. In conjunction with the loadings plot (Figure 3A), Figure 3B demonstrates the effects of storage time at $4^{\circ} \mathrm{C}$ on the functional performance of the cheese. Cheeses stored for 2 to $4 \mathrm{~d}$ at $4^{\circ} \mathrm{C}$ were situated mainly in quadrants I and IV, which corresponded to poor cheese functional- 
ity (positive scoring of PC1). With further storage time ( 8 to $32 \mathrm{~d}$ ), cheeses shifted gradually toward quadrants II and III and acquired a more desirable functionality as indicated by the negative scoring of $\mathrm{PC} 1$ which corresponded to higher values of $\mathrm{pH} 4.6 \mathrm{SN}, \mathrm{LT}_{\max }$, and flow, and lower values for COT and $\mathrm{EW}_{0}$. Figure $3 \mathrm{~B}$ thus illustrates how the functionality of the cheese improved with more negative scorings on $\mathrm{PC} 1$ or $\mathrm{PC} 2$, and we therefore considered the scorings on $\mathrm{PC} 1$ and $\mathrm{PC} 2$ as a measure for the overall functional performance of the cheese. Storage time mainly affected the cheese charac- teristics contributing to $\mathrm{PC} 1$ ( $\mathrm{pH} 4.6 \mathrm{SN}$, cohesiveness, springiness, $\mathrm{EW}_{0}, \mathrm{LT}_{\max }, \mathrm{COT}$, and flow; Figure 1) as compared with those contributing to $\mathrm{PC} 2$ ( $\mathrm{pH}$, soluble $\mathrm{Ca}$, firmness, and chewiness). For this reason, we denoted PC1 as the "major storage time-related" component and $\mathrm{PC} 2$ as the "minor storage time-related" component.

Figure 3B provides further insights in the variability between the cheeses sampled at the 7 production dates; quadrants I and II mainly contained cheeses from production dates $\mathrm{A}, \mathrm{B}$, and $\mathrm{F}$, which overall had
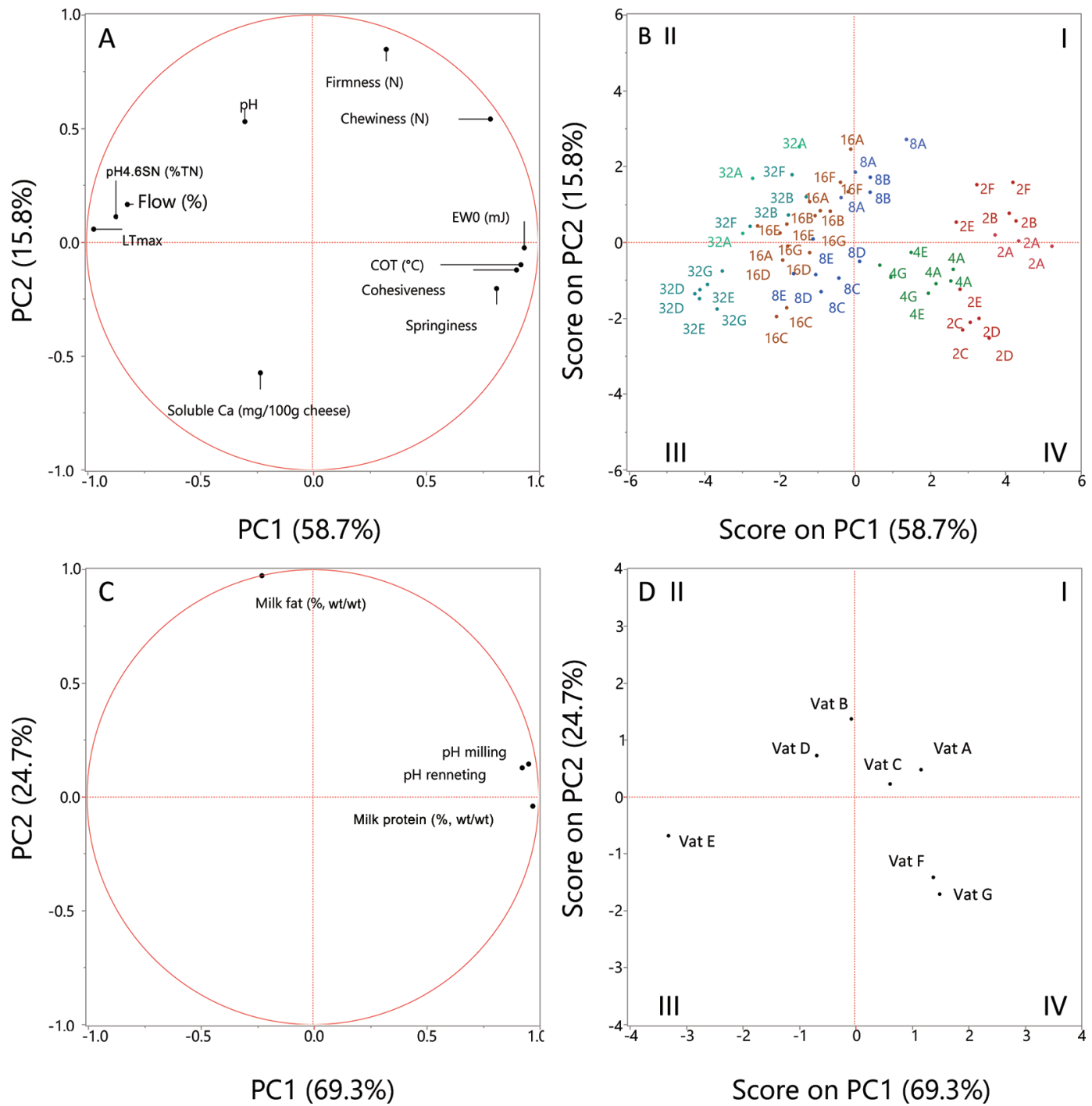

Figure 3. Loading (A, C) and scores (B, D) plots for low-moisture part-skim mozzarella obtained by principal component analysis. Plot A shows the variance in the physicochemical [pH, serum-soluble Ca, $\mathrm{pH} 4.6$ soluble $\mathrm{N}(\mathrm{pH} 4.6 \mathrm{SN})$ ] and functional variables [firmness, springiness, cohesiveness, chewiness, crossover temperature (COT), maximum value of the loss tangent $\left(\mathrm{LT}_{\max }\right)$, extension work at 0 min after melting $(\mathrm{EW})_{0}$, and flow] explained by 2 principal components (PC1 and PC2). Plot C shows the variance in cheesemaking-related variables (milk fat, milk protein, $\mathrm{pH}$ at rennet addition, and $\mathrm{pH}$ at curd milling) explained by $\mathrm{PC} 1$ and $\mathrm{PC} 2$. Score plots $\mathrm{B}$ and $\mathrm{D}$ illustrate the separation of cheeses sampled at different production dates (A, B, C, D, E, F, or G) based on their scorings on $\mathrm{PC} 1$ and $\mathrm{PC} 2$ during storage at $4^{\circ} \mathrm{C}$, such that the plots were divided into 4 quadrants (I, II, III, and IV). In plot B, the numbers $(0,2,4,8,16$, or 32$)$ correspond to the storage time at $4^{\circ} \mathrm{C}$, and the letters $(\mathrm{A}, \mathrm{B}, \mathrm{C}, \mathrm{D}, \mathrm{E}, \mathrm{F}$, or $\mathrm{G})$ to the production date (Table 1$)$. TN = total N. 
the highest scorings on $\mathrm{PC} 1$ and $\mathrm{PC} 2$ at each storage time. In contrast, quadrants III and IV mostly contained cheeses from production dates $\mathrm{C}, \mathrm{D}, \mathrm{E}$, or $\mathrm{G}$, which had the lowest scorings on PC1 and PC2, and had better functional performance. We could thus trace the observed variability in functional performance of industrial LMPS mozzarella during storage, as shown by the standard deviation in Figure 1, to these production dates (A, B, and $\mathrm{F}$ vs. $\mathrm{C}, \mathrm{D}, \mathrm{E}$, and $\mathrm{G}$ ) in particular, whereby the degree of variability is reflected by the distance between the different production dates in Figure 3B.

Variation in Cheesemaking Variables. The PCA of the cheesemaking variables, characterized by a variability greater than $1 \%$ (contents of milk fat and protein, and $\mathrm{pH}_{\text {renneting }}$ and $\mathrm{pH}_{\text {milling }}$ ) resulted in 2 principal components (PC1, PC2), which explained $94 \%$ of the cumulative variance (Figure $3 \mathrm{C}$ ). The variables milk protein, $\mathrm{pH}_{\text {renneting, }}$, and $\mathrm{pH}_{\text {milling }}$ contributed mainly to a positive scoring on $\mathrm{PC} 1$, and milk fat to a positive scoring on $\mathrm{PC} 2$. The former indicated a positive correlation between the variables milk protein content and the $\mathrm{pH}_{\text {renneting }}$ and $\mathrm{pH}_{\text {milling }}$ under standardized cheesemaking procedures; this reflects the importance of milk protein concentration in affecting buffering capacity and, therefore, the $\mathrm{pH}$ at different stages of cheese manufacture (Fox et al., 2017). We therefore accepted the linear combination of milk protein, $\mathrm{pH}_{\text {renneting }}$, and $\mathrm{pH}_{\text {milling }}$ into $\mathrm{PC} 1$ and denoted this as the "milk protein-related" component, and PC2 as the "milk fat-related" component. Figure 3D shows the resolution of the 7 production dates based on the "milk protein-related" component (PC1) and the "milk fat-related" component (PC2). Overall, cheese at production dates $\mathrm{E}, \mathrm{F}$, and $\mathrm{G}$ was produced with milk of lower fat content, relative to production dates $\mathrm{A}, \mathrm{B}, \mathrm{D}$, and $\mathrm{C}$ (Table 2). Cheeses from production dates B, D, and E had a lower scoring for the "milkprotein-related" component as compared with cheeses from production dates A, C, F, and G. Even though the protein content of the milk in production date $\mathrm{C}$ was numerically lower than that at production date $\mathrm{B}$ (Table 2), cheeses from production date $\mathrm{C}$ scored relatively higher on the "milk protein-related" component, indicating that the negative contribution of the lower milk protein content to $\mathrm{PC} 1$ was partially offset by the corresponding high value for $\mathrm{pH}_{\text {renneting. }}$.

We did not subject cheese-composition-related variables (contents of DM, FDM, MNFS, S/M, and Ca-toprotein) to PCA because no strong correlations could be demonstrated, with the exception of DM and MNFS.

Variability in Functional Performance of Industrial LMPS Mozzarella. The variability in "major storage time-related" and "minor storage timerelated" components in 59 LMPS mozzarella blocks from 7 cheese production dates after each storage time is presented in Figure 4. Overall, the variation of the "minor storage time-related" component was higher than that of the "major storage time-related" component, which was indicative of a relatively large variation in $\mathrm{pH}$, serum-soluble Ca, firmness, or chewiness of the unheated cheese.
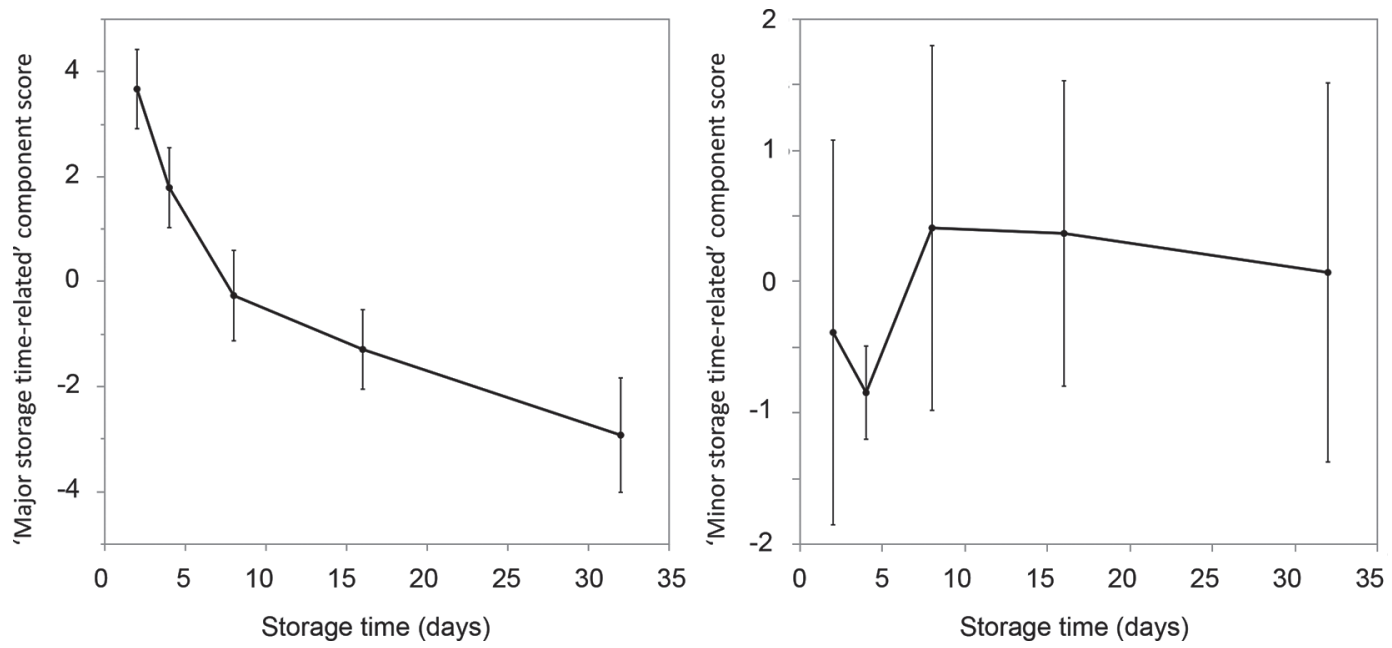

Figure 4. Changes during storage at $4^{\circ} \mathrm{C}$ in the scores on the "major storage time-related" and "minor storage time-related" components, which represent linear combinations of the physicochemical and functional variables of industrial low-moisture part-skim mozzarella, and are a measure for the overall functional performance of the cheese. The main variables included in the major [pH 4.6 soluble $\mathrm{N}$ (pH4.6SN), cohesiveness, springiness, $\mathrm{EW}_{0}$, maximum value of the loss tangent $\left(\mathrm{LT}_{\max }\right)$, crossover temperature (COT), and flow] and minor ( $\mathrm{pH}$, soluble Ca, firmness, and chewiness) time-dependent components were derived using principal component analysis (Figure 3). Presented data are mean values of cheeses produced on 7 different production dates; error bars represent the SD. 
The PCA showed that the cheeses from production dates $\mathrm{A}, \mathrm{B}$, and $\mathrm{F}$ could be separated from those of production dates $\mathrm{C}, \mathrm{D}, \mathrm{E}$, and $\mathrm{G}$ based on their physicochemical and functional characteristics (Figure $3 \mathrm{~B})$. The variation in functional performance between cheeses produced at different dates may be related to the variation in "milk fat-related" component, "milk protein-related" component, or contents of FDM, MNFS, S/M, and Ca. We applied 2-way ANOVA to assess the effects of these independent variables, storage time, and their interaction on the response components, separately. Variables found to have a significant effect were further analyzed using a linear model to identify which variable(s) contributed mostly to the observed variance in physicochemical and functional characteristics between the cheeses from the different production dates.

Effects of Manufacturing Variables and Cheese Composition on Cheese Functionality. The output of the 2-way ANOVA is presented in Supplemental Table S3 (https://doi.org/10.3168/jds.2020-19047). We found no interaction effects $(P>0.05)$ between the different variables and storage time on the "major storage time-related" or "minor storage time-related" components. The effects of storage time on the "major storage time-related" $(P<0.001)$ and "minor storage time-related" $(P>0.05)$ components were discussed above.

Two-way ANOVA revealed no effects $(P>0.05)$ of the "milk fat-related" component, FDM, or MNFS on the "major storage time-related" or "minor storage time-related" components. This is consistent with the small difference in fat content between the cheeses (Table 2).

The "milk protein-related" component $(P<0.05)$, S/M $(P<0.01)$, and Ca-to-protein $(P<0.001)$ affected the "major storage time-related" or "minor storage time-related" components; this is consistent with the data in Table 2 that showed relatively high variability for milk protein content, and for S/M content and $\mathrm{Ca}$ to-protein ratio of the cheese.

We constructed a linear model to evaluate the combined effects of the "milk protein-related" component, $\mathrm{S} / \mathrm{M}$, Ca-to-protein content, and storage time at $4^{\circ} \mathrm{C}$. The "milk protein-related" component (i.e., the factor that showed the least significant effect; Supplemental Table S3, https://doi.org/10.3168/jds.2020-19047) returned as nonsignificant in the combined model and was thus removed. The resulting model revealed that Ca-to-protein content $(P<0.01)$ and storage time $(P<0.001)$ were the only factors contributing to the variability in the "major storage time-related" component (Supplemental Table S4; https://doi.org/ 10.3168/jds.2020-19047). We therefore concluded that the variations in Ca-to-protein content of the cheese on the "major storage time-related" component outweighed the corresponding contributions of variations in "milk protein-related" component or S/M. The response curves (Figure 5) show that the score on the "major storage time-related" component of the cheese, which represents a linear combination of correlated physicochemical and functional variables ( $\mathrm{pH} 4.6 \mathrm{SN}$, cohesiveness, springiness, $\mathrm{EW}_{0}, \mathrm{LT}_{\max }$, COT, and flow), is a function of storage time at $4^{\circ} \mathrm{C}$ and $\mathrm{Ca}$ content. The PCA (Figure 3) showed that more negative scores coincide with more desirable functional characteristics (higher $\mathrm{LT}_{\max }$ and flow, lower COT). Hence, the storage time required to attain a desired level of functionality (i.e., a particular negative score on the "major storage time-related" component) depends on Ca content, with cheeses having a relatively low content in need of a shorter time and vice versa.

Furthermore, Ca-to-protein was found to be the only factor $(P<0.001)$ affecting the variability in the "minor storage time-related" component (Supplemental Table S4).

The effects of the Ca content on the overall functional performance of cheese after different storage times are shown in Figure 6, and demonstrate how the level of Ca consistently influenced the scorings on the "major storage time-related" and "minor storage time-related"

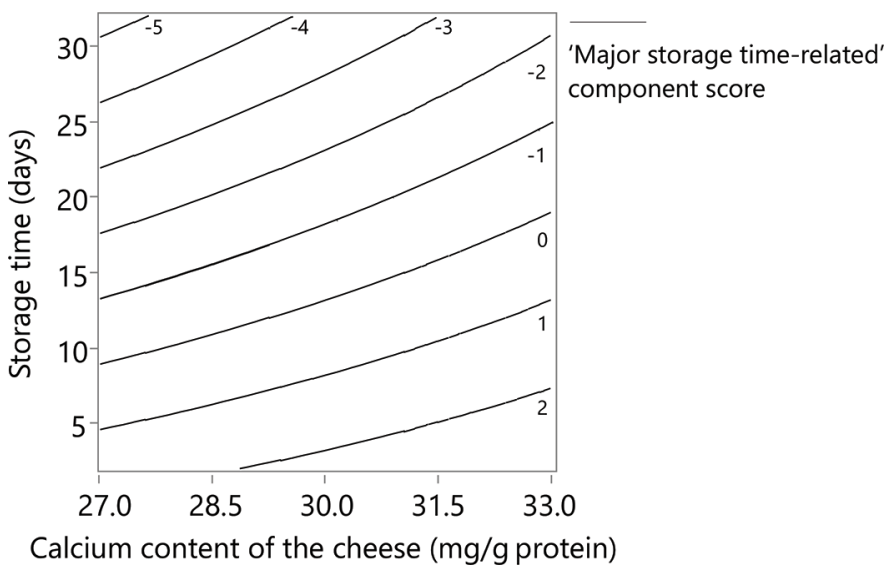

Figure 5. Contour plot for industrial low-moisture part-skim mozzarella showing the dependence of storage time at $4^{\circ} \mathrm{C}$ on calcium content of cheese in attaining a score of -5 to 2 units on the "major storage time-related" component [linear combination of cheese physicochemical and functional properties: $\mathrm{pH} 4.6$ soluble $\mathrm{N}(\mathrm{pH} 4.6 \mathrm{SN})$, cohesiveness, springiness, extension work at 0 min after melting $\left(\mathrm{EW}_{0}\right)$, maximum value of the loss tangent $\left(\mathrm{LT}_{\max }\right)$, crossover temperature (COT), and flow]. Each curve or score signifies an overall degree in functional performance of the cheese, as derived from principal component analysis (Figure 3). Curves with a more negative scoring for the "major storage time-related component" correspond to cheese with higher LT $_{\max }$ and flow of the heated cheese, and lower values for COT during heating and $\mathrm{EW}_{0}$, and thus are indicative of a more desirable cheese functionality. 
components after $2,8,16$, or $32 \mathrm{~d}$ of storage at $4^{\circ} \mathrm{C}$, and therefore the functional performance of the cheese. Higher Ca content resulted in firmer cheeses, and lower $\mathrm{Ca}$ content in better functional performance of the heated cheese, as demonstrated by higher negative score on the "major storage time-related" component. Hence, the $\mathrm{Ca}$ content is a critical factor modulating functionality and should be tightly controlled to produce cheese with consistent functional performance. The importance of $\mathrm{Ca}$ on the functionality of LMPS mozzarella confirms the findings of previous studies (Guinee et al., 2002; Joshi et al., 2004; Banville et al., 2013).

\section{CONCLUSIONS}

The LMPS mozzarella cheese was produced on industrial-scale following a standardized procedure. A total of 7 cheese vats and 75 blocks of cheese were sampled over a 1.5-yr period and characterized for their physicochemical and functional properties after 0,1 , $2,4,8,16$, or $32 \mathrm{~d}$ of storage at $4^{\circ} \mathrm{C}$. The functional performance of the heated cheese developed markedly during the first $16 \mathrm{~d}$, concomitant with a substantial increase in protein hydration, as measured by ${ }^{1} \mathrm{H}-$ NMR relaxometry, and a gradual increase in primary proteolysis ( $\mathrm{pH} 4.6 \mathrm{SN})$. Prolonging the storage time to $32 \mathrm{~d}$ resulted in a less significant change in cheese functionality. Despite the use of a defined manufacturing procedure, significant variation in the functional performance of the heated cheese obtained at different production dates was observed. Principal component analysis of the data revealed that variation in calcium content of the cheese (27.3 to $32.6 \mathrm{mg} / \mathrm{g}$ of protein) was the main cause of variability in the functionality of the unheated and heated cheese after different storage times. When heated, lower-calcium cheeses (27.3 to $28.5 \mathrm{mg} / \mathrm{g}$ of protein) were more fluid and flowable, and required less energy to extend than higher-calcium cheeses (30 to $32.6 \mathrm{mg} / \mathrm{g}$ of protein). The effects of high Ca content on the functional performance of the cheese can, however, be mitigated by prolonging the storage time at $4^{\circ} \mathrm{C}$. These findings are of relevance to manufacturers interested in the development of LMPS mozzarella variants with points of differentiation (e.g., in firmness, flow, stringiness, or shelf life) for different markets. Overall, the cheeses in this study were produced applying a subset of manufacturing condi-

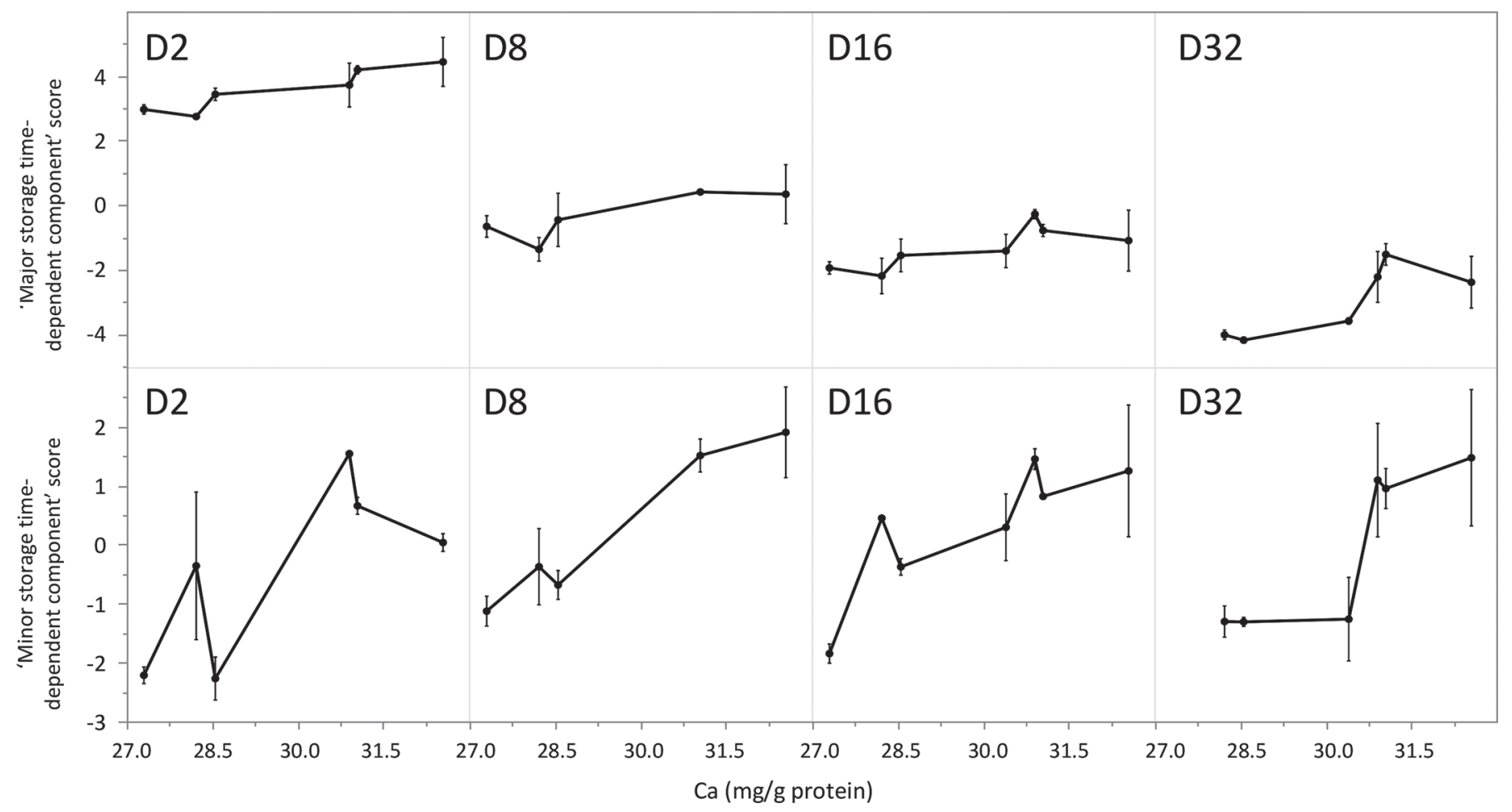

Figure 6. Scores on the "major storage time-related" and "minor storage time-related" components as a function of the variation in calcium content in industrial low-moisture part-skim mozzarella during $32 \mathrm{~d}$ of storage at $4^{\circ} \mathrm{C}$. The "major storage time-related" and "minor storage time-related" components correspond to linear combinations of functional performance-related variables as derived from principal component analysis, and are a measure for the overall functional performance of industrial low-moisture part-skim mozzarella cheese. Data illustrated are mean values of cheeses sampled on 7 different production dates. Error bars represent the SD. 
tions (e.g., relatively high $\mathrm{pH}$ at whey drainage, low $\mathrm{pH}$ at curd milling, high curd stretching temperature) that are found in commercial production of mozzarella and were characterized by a relatively high Ca content and low proteolysis. Hence, their application to LPMS mozzarella in general has to be considered with due consideration of the particular production conditions and composition of the cheese.

\section{ACKNOWLEDGMENTS}

The authors express their gratitude to John Tobin (Teagasc Food Research Centre Moorepark) for the provision of materials, equipment, and scientific support. This work was supported by the Flemish Agency for Innovation \& Entrepreneurship (grant number HBC.2017.0297, VLAIO, Belgium). The Fund for Scientific Research-Flanders (FWO-Vlaanderen, Belgium) is gratefully acknowledged for its financial support for obtaining the time-domain NMR equipment. There are no conflicts of interest.

\section{REFERENCES}

Banville, V., P. Morin, Y. Pouliot, and M. Britten. 2013. Physical properties of pizza Mozzarella cheese manufactured under different cheese-making conditions. J. Dairy Sci. 96:4804-4815. https://doi .org/10.3168/jds.2012-6314.

Chen, B., M. J. Lewis, and A. S. Grandison. 2014. Effect of seasonal variation on the composition and properties of raw milk destined for processing in the UK. Food Chem. 158:216-223. https://doi .org/10.1016/j.foodchem.2014.02.118.

Dave, R., P. Sharma, and D. McMahon. 2003. Melt and rheological properties of Mozzarella cheese as affected by starter culture and coagulating enzymes. Lait 83:61-77. https://doi.org/10.1051/lait: 2002050 .

Eurostat. 2020. Cows' milk collection and products obtained - monthly data [Data file]. Accessed Apr. 6, 2020. https://ec.europa.eu/ eurostat/web/main.

FDA. 2020. Electronic Code of Federal Regulations, Title 21, Chapter 1, Subchapter B, Part 133, Subpart B, 133.158. U.S. Dept. Health Human Services, United States Food and Drug Administration.

Feeney, E. P., P. F. Fox, and T. P. Guinee. 2001. Effect of ripening temperature on the quality of low moisture Mozzarella cheese: 1. Composition and proteolysis. Lait 81:463-474. https://doi.org/10 .1051/lait:2001145.

Fox, E. P., T. P. Guinee, T. M. Cogan, and P. L. McSweeney. 2017. Fundamentals of Cheese Science. 2nd ed. Springer, New York, NY.

Gianferri, R., V. D'Aiuto, R. Curini, M. Delfini, and E. Brosio. 2007. Proton NMR transverse relaxation measurements to study water dynamic states and age-related changes in Mozzarella di Bufala Campana cheese. Food Chem. 105:720-726. https://doi.org/10 .1016/j.foodchem.2007.01.005.

Guinee, T. P., E. P. Feeney, M. A. Auty, and P. F. Fox. 2002. Effect of $\mathrm{pH}$ and calcium concentration on some textural and functional properties of Mozzarella cheese. J. Dairy Sci. 85:1655-1669. https: //doi.org/10.3168/jds.S0022-0302(02)74238-0.

Guinee, T. P., E. P. Feeney, and P. F. Fox. 2001. Effect of ripening temperature on low moisture Mozzarella cheese: 2. Texture and functionality. Lait 81:475-485. https://doi.org/10.1051/lait: 2001146.

Guinee, T. P., D. Harrington, M. O. O. Corcoran, E. Mulholland, and C. Mujllins. 2000. The compositional and functional properties of commercial Mozzarella, cheddar and analogue pizza cheeses. Int.
J. Dairy Technol. 53:51-56. https://doi.org/10.1111/j.1471-0307 2000.tb02658.x.

Guinee, T. P., E. O. Mulholland, C. Mullins, M. O. Corcoran, J. F. Connolly, T. Beresford, R. Mehra, B. J. O'Brien, J. J. Murphy, G. Stakelum, and D. Harrington. 1998. Effect of altering the daily herbage allowance to cows in mid lactation on the composition, ripening and functionality of low-moisture, part-skim Mozzarella cheese. J. Dairy Res. 65:23-30. https://doi.org/10.1017/ S0022029997002665.

Gulati, A., N. Galvin, D. Hennessy, S. McAuliffe, M. O'Donovan, J. J. McManus, M. Fenelon, and T. P. Guinee. 2018. Grazing of dairy cows on pasture versus indoor feeding on total mixed ration: Effects on low-moisture part-skim Mozzarella cheese yield and quality characteristics in mid and late lactation. J. Dairy Sci. 101:8737-8756. https://doi.org/10.3168/jds.2018-14566.

Gulati, A., D. Hennessy, M. O'Donovan, J. J. McManus, M. Fenelon, and T. P. Guinee. 2019. Dairy cow feeding system alters the characteristics of low-heat skim milk powder and processability of reconstituted skim milk. J. Dairy Sci. 102:8630-8647. https://doi .org $/ 10.3168 /$ jds.2018-15884

Guo, M. R., J. A. Gilmore, and P. S. Kindstedt. 1997. Effect of sodium chloride on the serum phase of Mozzarella cheese. J. Dairy Sci. 80:3092-3098. https://doi.org/10.3168/jds.S0022-0302(97)76279 $-9$.

Guo, M. R., and P. S. Kindstedt. 1995. Age-related changes in the water phase of Mozzarella cheese. J. Dairy Sci. 78:2099-2107. https:/ /doi.org/10.3168/jds.S0022-0302(95)76836-9.

Hassan, A., M. E. Johnson, and J. A. Lucey. 2004. Changes in the proportions of soluble and insoluble calcium during the ripening of Cheddar cheese. J. Dairy Sci. 87:854-862. https://doi.org/10 .3168/jds.S0022-0302(04)73229-4.

Imm, J. Y., E. J. Oh, K. S. Han, S. Oh, Y. W. Park, and S. H. Kim. 2003. Functionality and physico-chemical characteristics of bovine and caprine Mozzarella cheeses during refrigerated storage. J. Dairy Sci. 86:2790-2798. https://doi.org/10.3168/jds.S0022 -0302(03)73876-4.

Joshi, N. S., K. Muthukumarappan, and R. I. Dave. 2004. Effect of calcium on microstructure and meltability of part skim Mozzarella cheese. J. Dairy Sci. 87:1975-1985. https://doi.org/10.3168/jds .S0022-0302(04)70014-4.

Kindstedt, P. S., M. Caric, and S. Milanovic. 2004. Pasta-filata cheeses. Pages 251-276 in Cheese Chemistry, Physics and Microbiology, Vol. 2, Major Cheese Groups. 3rd ed. P. F. Fox, P. L. H. McSweeney, T. M. Cogan, and T. P. Guinee, ed. Elsevier Academic Press, London, UK.

Kindstedt, P. S., M. R. Guo, W. H. Viotto, J. J. Yun, and D. M. Barbano. 1995. Effect of screw speed and residence time at high stretching temperature on composition, proteolysis, functional properties and the water phase of Mozzarella cheese. Pages 56-72 in Proceedings of the 32nd Annual Marschall Italian and Specialty Cheese Seminar, Rhone Poulenc Dairy Ingredients, Madison, WI.

Kuo, M. I., and S. Gunasekaran. 2009. Effect of freezing and frozen storage on microstructure of Mozzarella and pizza cheeses. Lebensm. Wiss. Technol. 42:9-16. https://doi.org/10.1016/j.lwt.2008 .07 .003 .

Lin, Y., A. L. Kelly, J. A. O'Mahony, and T. P. Guinee. 2017. Addition of sodium caseinate to skim milk increases nonsedimentable casein and causes significant changes in rennet-induced gelation, heat stability, and ethanol stability. J. Dairy Sci. 100:908-918. https://doi .org/10.3168/jds.2016-11704.

Lucey, J. A., M. E. Johnson, and D. S. Horne. 2003. Invited review: perspectives on the basis of the rheology and texture properties of cheese. J. Dairy Sci. 86:2725-2743. https://doi.org/10.3168/jds .S0022-0302(03)73869-7.

McMahon, D. J., R. M. Fife, and C. J. Oberg. 1999. Water partitioning in Mozzarella cheese and its relationship to cheese meltability. J. Dairy Sci. 82:1361-1369. https://doi.org/10.3168/jds.S0022 -0302(99)75361-0.

McMahon, D. J., and C. J. Oberg. 2017. Pasta-filata cheeses. Pages 1041-1068 in Cheese: Chemistry, Physics and Microbiology. 4th 
ed. P. L. H. McSweeney, P. F. Fox, P. D. Cotter, and D. W. Everett, ed. Academic Press, Cambridge, MA.

Metzger, L. E., D. M. Barbano, and P. S. Kindstedt. 2001. Effect of milk preacidification on low fat Mozzarella cheese: III. Post-melt chewiness and whiteness. J. Dairy Sci. 84:1357-1366. https://doi .org/10.3168/jds.S0022-0302(01)70166-X.

O'Mahony, J. A., P. L. H. McSweeney, and J. A. Lucey. 2006. A model system for studying the effects of colloidal calcium phosphate concentration on the rheological properties of Cheddar cheese. J. Dairy Sci. 89:892-904. https://doi.org/10.3168/jds.S0022-0302(06)72154 -3 .

Oberg, C. J., W. R. McManus, and D. J. McMahon. 1993. Microstructure of Mozzarella cheese during manufacture. Food Struct. $12: 251-258$.

Renda, A., D. M. Barbano, J. J. Yun, P. S. Kindstedt, and S. J. Mulvaney. 1997. Influence of screw speeds of the mixer at low temperature on characteristics of Mozzarella cheese. J. Dairy Sci. 80:19011907. https://doi.org/10.3168/jds.S0022-0302(97)76130-7.

Sharma, P., P. A. Munro, T. T. Dessev, and P. G. Wiles. 2016. Shear work induced changes in the viscoelastic properties of model Mozzarella cheese. Int. Dairy J. 56:108-118. https://doi.org/10.1016/ j.idairyj.2016.01.010.

Smith, J. R., J. P. Hindmarsh, A. J. Carr, M. D. Golding, and D. Reid. 2017. Molecular drivers of structural development in Mozzarella cheese. J. Food Eng. 214:257-265.

To, C. M., L. Vermeir, F. Rebry, B. Kerkaert, P. Van der Meeren, and T. P. Guinee. 2020. Impact of freezing on the physicochemical and functional properties of low-moisture part-skim Mozzarella. Int. Dairy J. 106:104704. https://doi.org/10.1016/j.idairyj.2020 .104704 .
Upreti, P., L. E. Metzger, and K. D. Hayes. 2006. Influence of calcium and phosphorus, lactose, and salt-to-moisture ratio on Cheddar cheese quality: Proteolysis during ripening. J. Dairy Sci. 89:444453. https://doi.org/10.3168/jds.S0022-0302(06)72108-7.

Vermeir, L., A. Declerck, C. M. To, B. Kerkaert, and P. Van der Meeren. 2019. Water and oil signal assignment in low-moisture Mozzarella as determined by time-domain NMR T2 relaxometry. Magn. Reson. Chem. 57:674-685. https://doi.org/10.1002/mrc .4842 .

Walstra, P., J. T. M. Wouters, and T. J. Geurts. 2006. Dairy Science and Technology. 2nd ed. Taylor \& Francis Group, Boca Raton, FL.

Yun, J. S., L. J. Kiely, D. M. Barbano, and P. S. Kindstedt. 1993a. Mozzarella cheese: Impact of cooking temperature on chemical composition, proteolysis and functional properties. J. Dairy Sci 76:3664-3673. https://doi.org/10.3168/jds.S0022-0302(93)77708 -5 .

Yun, J. S., L. J. Kiely, P. S. Kindstedt, and D. M. Barbano. 1993b. Mozzarella cheese: Impact of milling $\mathrm{pH}$ on functional properties. J. Dairy Sci. 76:3639-3649. https://doi.org/10.3168/jds.S0022 -0302(93)77705-X.

\section{ORCIDS}

C. M. To ๑ https://orcid.org/0000-0002-6796-4811

L. Vermeir @ https://orcid.org/0000-0002-9768-8010

P. Van der Meeren (1) https://orcid.org/0000-0001-5405-4256

T. P. Guinee @ https://orcid.org/0000-0002-6389-9717 